\title{
THE ASSESSMENT OF THE ERGONOMIC SUITABILITY OF VEHICLES INTENDED FOR EMPLOYEES WITH PHYSICAL DISABILITIES - THE AHP APPROACH
}

UDC 331.101.1:629.113.2:364.4-056.24/.36

\author{
Lutvo Haznadarevic ${ }^{1}$, Novak Milosevic ${ }^{2}$, Evica Stojiljkovic \\ ${ }^{1}$ College „Logos Centar“ Mostar, Mostar, Bosnia and Herzegovina \\ ${ }^{2}$ College of Vocational Studies, Belgrade Polytecnic, Belgrade, Serbia \\ ${ }^{3}$ University of Niš, Faculty of Occupational Safety in Niš, Niš, Serbia
}

\begin{abstract}
The protection of rights and disabled persons' safety are the most sensitive elements of social development policy, and also economic and social policy. Nowadays, disability should be viewed from a human rights perspective. One of the problems pertaining to the employment of persons with physical disabilities is infrastructure (architectural barriers) on the one hand, and organized transport on the other. The main objective of this paper is to consider the issue of transportation for employees with physical disabilities, which is a significant factor for providing employment opportunities for these persons in the Republic of Serbia. The overall aim of this paper is to determine the ergonomically most suitable and economically acceptable technical solution using the AHP method when adapting the existing vehicles into the vehicles intended for the transport of persons with mobility impairments.
\end{abstract}

Key words: Analytic Hierarchy Process (AHP), corrective ergonomics, disability, transportation of employees with physical disabilities, lifting platform for a wheelchair, cassette wheelchair lift for mini-bus, cassette wheelchair lift for bus, ramp.

\section{INTRODUCTION}

Disability is a complex social phenomenon that practically appears in all areas of modern life and requires a multi-sectoral approach and cooperation between different bodies of authorities, local governments, civil society, the disabled themselves and their organizations. Special emphasis is placed on guarantees of equality to persons with disabilities, nondiscrimination and their full participation in society, i.e. the collective [1].

Received August 12, 2019 / Accepted September 10, 2019

Corresponding author: Lutvo Haznadarevic

College „Logos Centar“" Mostar, Bišće polje bb, Mostar, Bosnia and Herzegovina

E-mail: hlutvo@yahoo.com 
The number of persons with disabilities and the percentage they make up of the overall population varies across the regions and parts of the world, due to differences in methodology which refers to both data collection and data generation (censuses, surveys, etc.), as well as due to diverse definitions of the term "disability". In the Republic of Serbia, it is estimated that there are about 700,000 people with disabilities; however, there are no official data about the exact number and disability grading [2].

Such data only indicate that we must pay special attention to all persons with some form of disability in order to facilitate their integration into society or the collective, and ensure the full enjoyment of all rights that belong to them. Although each disability group requires special attention, and also a separate analysis and approach to problem-solving due to the nature of the disability, the focus of this paper shall be on the persons with movement disabilities, i.e. the persons with lower extremity functional loss. Since they have difficulties to move, this requires certain changes and adaptations both by the persons with this type of disability and the society, i.e. the collective. Therefore, the main objective of this paper is to scrutinize the problems of transportation of employees with lower limb immobility, which is one of the main obstacles in their employment.

Also, one of the problems pertaining to the employment of persons with physical disabilities is infrastructure (architectural barriers) on the one hand, and organized transport on the other. Many employers cannot offer the job to the persons with movement disabilities due to the lack of disability-related capacities that were not included at the stage of building design.

In our country, this problem was recognized two decades ago when the legal framework was created, which afterward resulted in the adoption of the Planning and Construction Act in 2009. This Law stipulates that "buildings for public and business purposes, as well as other public buildings (streets, squares, parks, etc.), must be designed, built and maintained so that they provide to all users, especially persons with disabilities, children and the elderly, an unimpeded access, movement and residence, or the use in accordance with the relevant technical regulations... " [3]. Unfortunately, although the above-mentioned Law came into force two decades ago, we often see that many public buildings are still not accessible for persons with physical disabilities. Apart from inaccessible entrances, the evidence to this is the results of the most recent Serbian research on social integration of persons with disabilities and the employment issues. The research shows that the most frequent response by the persons with disabilities when asked to "make a list" of the most common obstacles they face on a daily basis, is "a large number of architectural barriers" [4]. On the other hand, organized transport to the workplace is another important prerequisite when hiring disabled persons.

For people with disabilities, transportation can be organized in two ways:

1) The first option involves using accessible public transportation, where individual vehicles (low-floor vehicles) are equipped with the appropriate platform designed for wheelchair access.

2) The second option involves a special shuttle van, which provides door-to-door service; in this case, the disabled persons should apply to the City administration, and then the vehicle should pick them up at a scheduled time and take them to their workplaces.

However, in spite of the aforementioned ways of organizing transportation for persons with physical disabilities, there are many problems that can occur in practice. When it comes to public transport vehicles with built-in passenger ramps in the so-called low 
floor, they are not a guarantee, either to the persons with disabilities that they will get into these vehicles or to the employers that their workers will arrive on time. Another problem with public transportation is an insufficient number of low-floor vehicles with ramped access for disabled people. Moreover, GSP Belgrade is the only company in Serbia that has some kind of specialized transport, which involves door-to-door transportation of disabled persons. Besides, the problem, in this case, is an insufficient number of these vehicles that would satisfy the overall market, on the one hand, and the insufficient space (comfort) in the vehicle itself to accommodate more disabled persons on the other. The above reasons were the main motive for research and analysis of modern ergonomic solutions, which can be used to address the problem of organized transport of disabled persons in the Republic of Serbia. Choosing an economically justified ergonomic solution for the transportation of persons with disabilities in our country can contribute to satisfying one of the basic requirements for the successful employment of these persons. Also, the employers would feel more secure about their employees arriving to work on time, as well as their safe return homes.

\section{METHODOLOGY}

Providing transport to people with disabilities to their workplaces and choosing the most ergonomically acceptable solution depends primarily on the financial capabilities of the country or the town. Two basic approaches to solving the problem of organized transportation of employees with physical disabilities are:

1) Purchase of new (modern) vehicles adapted solely to transport disabled persons

2) Adaptation of existing vehicles to the needs of disabled persons, by applying corrective ergonomics, installing auxiliary equipment (Ramps, Cassette wheelchair lift for bus, Cassette wheelchair lift for mini-bus, Lifting platform for a wheelchair) intended for the smooth entry and exit from the vehicle.

The most efficient solution would certainly be the first one which involves the purchase of new vehicles designed for the transport of disabled persons. However, it is not always feasible, primarily due to financial reasons, since this approach involves not only the purchase of new vehicles but also an additional expansion of technological capacities and investments (the space for garages, maintenance, services, etc.).

A more practical and feasible solution is the second approach, by which the existing vehicles should be adapted to the transportation of the disabled people. The problem here refers to the most appropriate solutions for retrofitting the existing vehicles. This entails various criteria for consideration when making a final decision. In case of making decisions about retrofitting already existing vehicles to the disabled persons and choosing the most economically viable and ergonomically suitable solution from the many alternatives (Ramps, Cassette wheelchair lift for bus, Cassette wheelchair lift for minibus, Lifting platform for a wheelchair), we used the AHP method.

The original AHP (Analytic Hierarchy Process) was developed by Thomas L. Saaty [5]. Multi-criteria decision-making process is an integrated evaluation process, where multiple attributes are used to obtain the results of integrated decision-making [6].

The AHP method is one of the most famous and most frequently used methods in decision situations, when the decision-making process, or choosing and ranking of the 
available alternatives is based on multiple attributes (criteria) of different importance and expressed by different scales. It allows for flexibility in the decision-making process and helps decision-makers to set priorities and make good decisions, taking into account the qualitative/quantitative aspects of the decision [7].

AHP is a multi-criteria method based on the disaggregation of a more complex problem on several levels of hierarchy with an established objective on the top as the first level. The following level is criteria and sub-criteria whereas the final level shows the alternatives. Three levels constitute the basics of AHP hierarchy (objective, criteria and, alternatives); however, it is achievable to further disaggregate this structure.

Methodologically speaking, the AHP is a multi-criteria technique that is based on decomposing a complex problem in a hierarchy. The goal is at the top of the hierarchy, while the criteria, sub-criteria and alternatives are at the lower levels [8]. Hence, the approach for defining problems is from top to bottom (top-down). AHP allows evaluation of levels in both directions (top-down) and (bottom-up), while in practice the evaluation starts from the top, i.e. the evaluation of criteria related to objectives, sub-criteria related to criteria, alternatives related to sub-criteria $[9,10]$. The final result of an AHP method is a list of relevant alternatives related to the objective.

The pairwise comparison scale $[11,12]$ by Saaty scale is presented in Table 1, which is considered as a base for AHP implementation.

Table 1 The pairwise comparison scale

\begin{tabular}{|c|c|c|}
\hline $\begin{array}{l}\text { Intensity of } \\
\text { importance }\end{array}$ & Definition & Explanation \\
\hline 1 & Equal importance & Two activities contribute equally to the objective \\
\hline 3 & Moderate importance & $\begin{array}{l}\text { Experience and judgment slightly favour one activity } \\
\text { over another }\end{array}$ \\
\hline 5 & Strong importance & $\begin{array}{l}\text { Experience and judgment strongly favour one activity } \\
\text { over another }\end{array}$ \\
\hline 7 & $\begin{array}{l}\text { Very strong or } \\
\text { demonstrated importance }\end{array}$ & $\begin{array}{l}\text { An activity is favoured very strongly over another; its } \\
\text { dominance demonstrated in practice }\end{array}$ \\
\hline 9 & Extreme importance & $\begin{array}{l}\text { The evidence favouring one activity over another is of } \\
\text { the highest possible order of affirmation }\end{array}$ \\
\hline $2,4,6,8$ & Intermediate values & \\
\hline
\end{tabular}

AHP method, used for selecting, consists of the following steps [13, 14]:

- The overall goal (objective) is identified and clearly defined.

- The criteria, sub-criteria and alternatives which contribute to the overall goal are identified.

- The hierarchical structure is formed.

- A pairwise comparison is made.

- The priority weights vector is estimated by using the eigenvalue method.

- The consistency of judgments is checked.

- The global priority vector is calculated. 
When it is assumed that $\left(A_{1}, A_{2}, \ldots, A_{n}\right)$ is any set of $n$ elements, then a sample of a square matrix can be produced as below by pairwise comparisons of each element. Here, each $\left(A_{i}, A_{j}\right)$ judgment is represented as $a_{i j}$. Because $a_{i i}=1$, for all $i$ the diagonal of the matrix contains entries of 1 .

$$
\left(\begin{array}{llll}
a_{11} & a_{12} & \ldots & a_{1 n} \\
a_{21} & a_{22} & \ldots & a_{2 n} \\
\vdots & \vdots & & \vdots \\
a_{n 1} & a_{n 2} & \ldots & a_{n m}
\end{array}\right)
$$

When $\left(w_{1}, w, \ldots, w_{n}\right)$ are the elements of corresponding weights; the dominance of an element in the row over the element in the column is represented as $w_{i} / w_{j}$

AHP method compares the related weights of each element concerning the goal. The general form of a comparison matrix of AHP is given as follows:

$$
A=\left(\begin{array}{cccc}
\frac{w_{1}}{w_{1}} & \frac{w_{1}}{w_{2}} & \ldots & \frac{w_{1}}{w_{n}} \\
\frac{w_{2}}{w_{1}} & \frac{w_{2}}{w_{2}} & \ldots & \frac{w_{2}}{w_{n}} \\
\vdots & \vdots & & \vdots \\
\frac{w_{n}}{w_{1}} & \frac{w_{n}}{w_{n}} & \ldots & \frac{w_{n}}{w_{m}}
\end{array}\right)
$$

Then the problem turns into a general process for calculating the largest eigenvalue corresponding to eigenvector to assess the Consistency Index (C.I.), where A is the matrix, $x$ is the eigenvector and $\lambda$ is the eigenvalue. When we divide C.I. by the random consistency number, the final value must be less than 0.10 [15].

$$
\begin{gathered}
A x=\lambda x \\
\text { C.I. }=\frac{\lambda_{\max }-n}{n-1}
\end{gathered}
$$

The main advantage of an AHP approach is that, apart from individual decision making, it allows group decision making. Previously described procedures related to individual decision making represent the basics of group evaluation where we have more decisionmakers with fundamental differences concerning the summary of final results. Moreover, individual decision making is also very useful to derive rank lists and prioritize.

\section{RESULTS}

Based on the clearly stated problem of "selecting the ergonomically most suitable solution for retrofitting the existing vehicles to vehicles intended for special purposes and transport of disabled people who use wheelchairs", we have obtained the following results using the AHP method. 
The research goal, the alternatives considered as the most suitable solution, and the criteria (attributes) based on which the alternatives are considered to constitute the structure of the research problem shown in Figure 1.

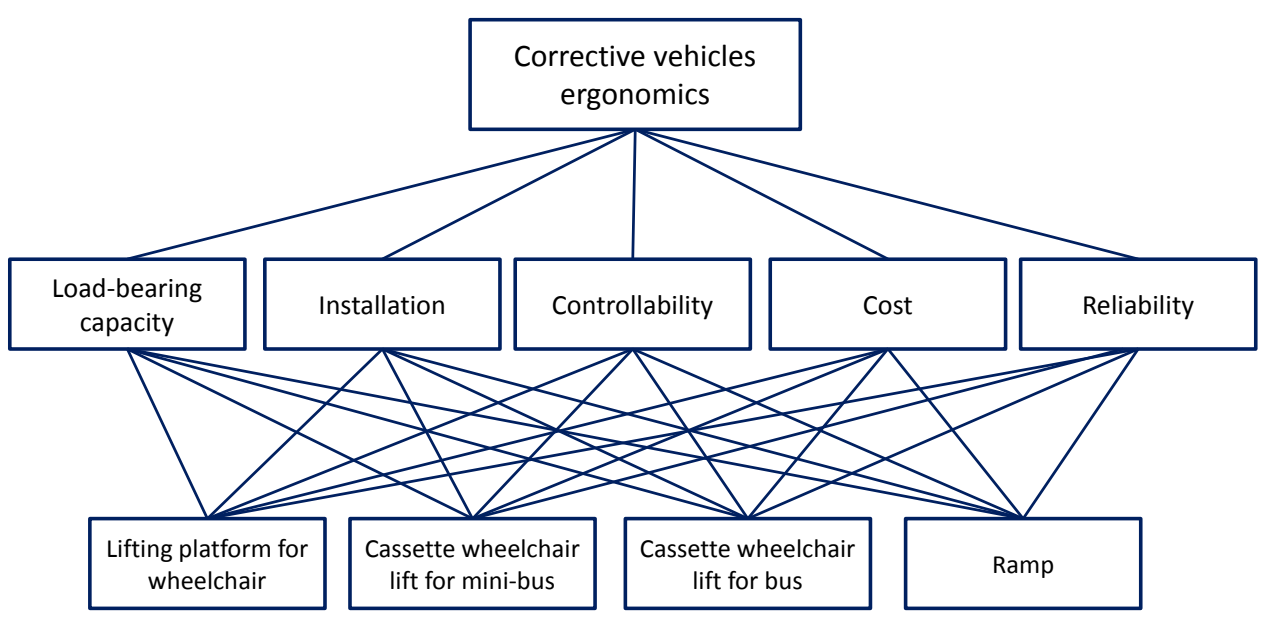

Fig. 1 Structure of the research problem

We used the following comparative data to select the best ergonomic solution using the approximate and computer-supported AHP method (Table 2):

- K1 - Maximum load (kg)

- K2 - Installation possibility

- K3 - Controllability

- K4-Cost (€)

- K5 - Reliability

Table 2 Criteria for assessing the ergonomic suitability of the vehicle

$\left.\begin{array}{lccccc}\hline & \text { K1 } & \text { K2 } & \text { K3 } & \text { K4 } & \text { K5 } \\ \hline \text { A1 } & \text { 340 kg } & \text { easy } & \text { automatic } & 29.900 € & \text { high } \\ \text { A2 } & 350 \mathrm{~kg} & \text { medium-easy } & \text { semi-automatic } & 25.000 € & \text { average } \\ \text { A3 } & 360 \mathrm{~kg} & \text { medium-difficult } & \text { semi-automatic } & 27.000 € & \text { average } \\ \text { A4 } & 600 \mathrm{~kg} & \text { easy } & \text { manual } & 15.000 € & \text { very high }\end{array}\right\}$

By comparing the importance of individual criteria according to Saaty's " 1 to 9" scale, we defined the decision matrix and normalized the obtained values (Table 3 ). 
Table 3 The comparison of the importance of criteria

\begin{tabular}{lccccc}
\hline & $\begin{array}{c}\text { Load-bearing } \\
\text { capacity }\end{array}$ & Installation & Controllability & Cost & Reliability \\
\hline Load-bearing capacity & 1 & 0,2 & 0,333 & 0,143 & 0,333 \\
Installation & 5 & 1 & 5 & 0,333 & 5 \\
Controllability & $\left\{\begin{array}{c}\text { Cost } \\
3\end{array}\right.$ & 3 & 1 & 0,143 & 0,333 \\
Reliability & 7 & 0,2 & 3 & 1 & 5 \\
$\Sigma$ & & 4,6 & 16,333 & 1,819 & 11,666 \\
\hline
\end{tabular}

The decision maker's rating for the given criterion $(\bar{x})$, i.e. rating the quality of the individual criteria is presented in the following matrix.

Table 4 Rating the quality of the individual criteria

\begin{tabular}{lcccccc}
\hline & $\begin{array}{c}\text { Load-bearing } \\
\text { capacity }\end{array}$ & Installation & Controllability & Cost & Reliability & $\bar{x}$ \\
\hline Load-bearing capacity & 0,053 & 0,043 & 0,020 & 0,079 & 0,029 & $\mathbf{0 , 0 4 5}$ \\
Installation & 0,263 & 0,217 & 0,306 & 0,183 & 0,429 & $\mathbf{0 , 2 8 0}$ \\
Controllability & 0,158 & 0,043 & 0,061 & 0,079 & 0,029 & $\mathbf{0 , 0 7 4}$ \\
\hline Cost & 0,368 & 0,652 & 0,429 & 0,550 & 0,429 & $\mathbf{0 , 4 8 6}$ \\
\hline Reliability & 0,158 & 0,043 & 0,184 & 0,110 & 0,086 & $\mathbf{0 , 1 1 6}$ \\
\hline
\end{tabular}

The rating obtained in this way can be interpreted as the weighted preference of one alternative over the others, and it represents the weights we shall use to make the final decision. With this approach, we get more accurate and fixed solutions. They are more accurate due to pairwise comparisons, and also more fixed because a small change in values will not cause great changes in final assessments.

The selection of the most significant alternative, in this case the design solution, for each criterion separately, is presented in the following matrices according to the same principle.

Table 5 Assessments and priorities pertaining to Load-Bearing Capacity:

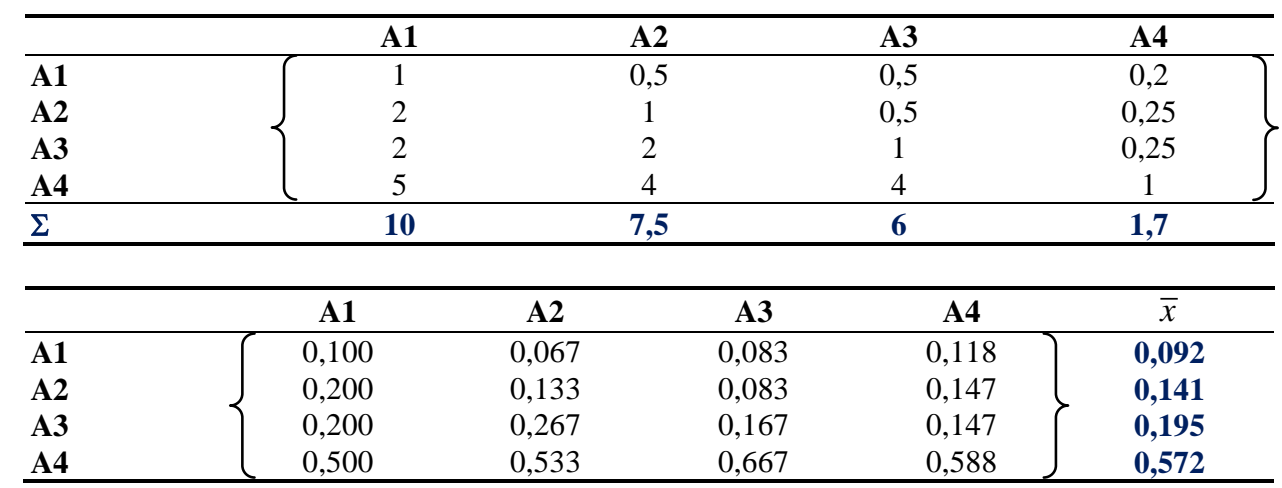


Table 6 Assessments and priorities pertaining to Installation:

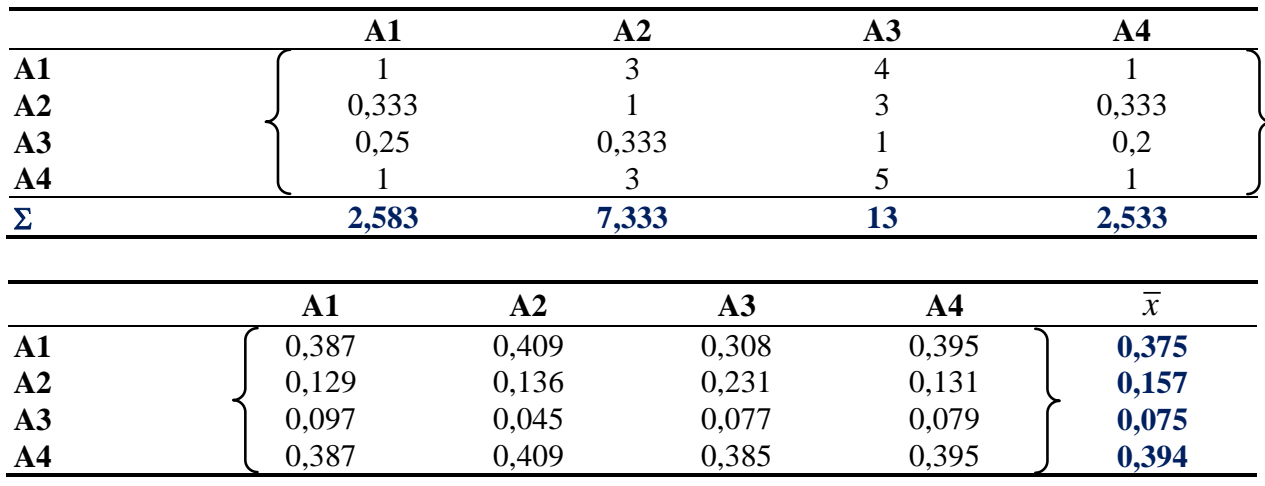

Table 7 Assessments and priorities pertaining to Controllability:

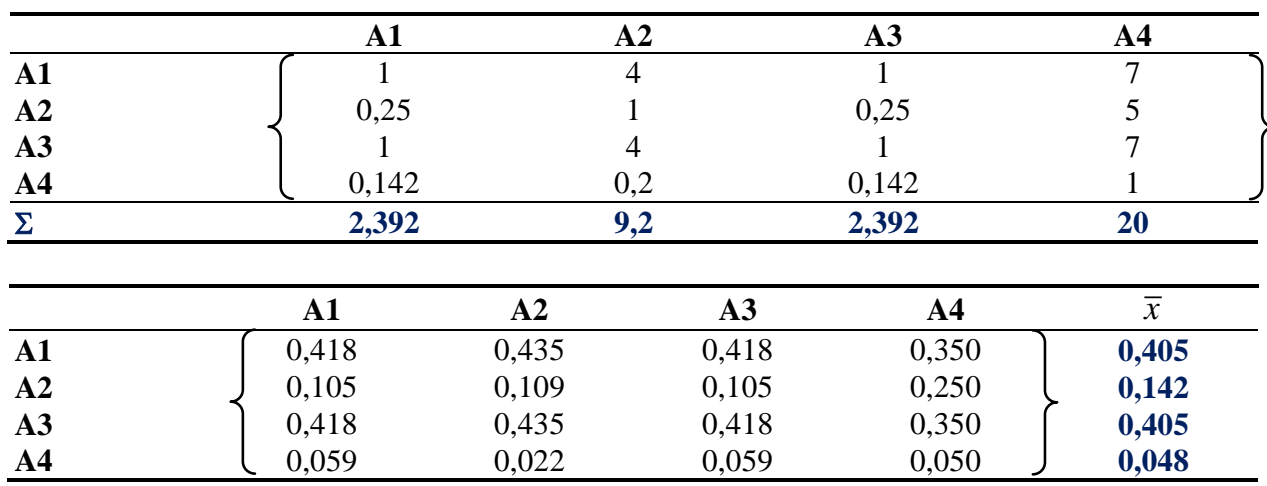

Table 8 Assessments and priorities pertaining to Cost:

\begin{tabular}{|c|c|c|c|c|c|}
\hline & A1 & \multicolumn{2}{|c|}{ A2 } & A3 & A4 \\
\hline A1 & 1 & \multicolumn{2}{|c|}{0,333} & 0,5 & 0,142 \\
\hline A2 & 3 & \multicolumn{2}{|c|}{1} & 2 & 0,2 \\
\hline A3 & 2 & \multicolumn{2}{|c|}{0,5} & 1 & 0,166 \\
\hline A4 & 7 & \multicolumn{2}{|c|}{5} & 6 & 1 \\
\hline \multirow[t]{2}{*}{$\Sigma$} & \multicolumn{2}{|c|}{13} & & 9,5 & $\mathbf{1 , 5 0 8}$ \\
\hline & A1 & A2 & A3 & A4 & $\bar{x}$ \\
\hline A1 & 0,077 & 0,049 & 0,053 & 0,093 & 0,068 \\
\hline A2 & 0,231 & 0,146 & 0,211 & 0,133 & 0,180 \\
\hline A3 & 0,154 & 0,073 & 0,105 & 0,110 & 0,111 \\
\hline A4 & 0,538 & 0,732 & 0,632 & 0,663 & 0,641 \\
\hline
\end{tabular}


Table 9 Assessments and priorities pertaining to Reliability:

\begin{tabular}{|c|c|c|c|c|c|}
\hline & A1 & \multicolumn{2}{|c|}{ A2 } & A3 & \multirow{2}{*}{$\begin{array}{c}\mathbf{A 4} \\
0,333\end{array}$} \\
\hline A1 & 1 & & & 5 & \\
\hline A2 & 0,2 & & & 1 & 0,166 \\
\hline A3 & 0,2 & & & 1 & 0,166 \\
\hline A4 & 3 & & & 6 & 1 \\
\hline \multirow[t]{2}{*}{$\Sigma$} & 4,4 & & & 13 & 1,665 \\
\hline & A1 & A2 & A3 & A4 & $\bar{x}$ \\
\hline A1 & 0,227 & 0,385 & 0,385 & 0,200 & 0,299 \\
\hline A2 & 0,045 & 0,077 & 0,077 & 0,100 & 0,075 \\
\hline A3 & 0,045 & 0,077 & 0,077 & 0,100 & 0,075 \\
\hline A4 & 0,682 & 0,462 & 0,462 & 0,601 & 0,551 \\
\hline
\end{tabular}

The following table shows the decision matrix.

Table 10 Decision matrix

$\left.\begin{array}{lccccc}\hline \multicolumn{1}{c}{} & \text { K1 } & \text { K2 } & \text { K3 } & \text { K4 } & \text { K5 } \\ \hline \text { A1 } & 0,092 & 0,375 & 0,405 & 0,068 & 0,299 \\ \text { A2 } & \{, 141 & 0,157 & 0,142 & 0,180 & 0,075 \\ \text { A3 } & \{, 195 & 0,075 & 0,405 & 0,111 & 0,075 \\ \text { A4 } & 0,572 & 0,394 & 0,048 & 0,641 & 0,551\end{array}\right\}$

Based on additive weights (Table 11), we decided which design solution (alternative) is the best for the observed research problem.

Table 11 Choosing the most ergonomically suitable vehicle

\begin{tabular}{|c|c|c|}
\hline & Weighted sum & $\Sigma$ \\
\hline A1 & $0,092 \cdot 0,045+0,375 \bullet 0,280+0,405 \bullet 0,074+0,068 \bullet 0,486+0,299 \bullet 0,116$ & 0,207 \\
\hline A2 & $0,141 \bullet 0,045+0,157 \bullet 0,280+0,142 \bullet 0,074+0,180 \bullet 0,486+0,075 \bullet 0,116$ & 0,157 \\
\hline A3 & $0,195 \bullet 0,045+0,075 \bullet 0,280+0,405 \bullet 0,074+0,111 \bullet 0,486+0,075 \bullet 0,116$ & $\mathbf{0 , 1 2 1}$ \\
\hline A4 & $0,572 \bullet 0,045+0,394 \bullet 0,280+0,048 \bullet 0,074+0,641 \bullet 0,486+0,551 \bullet 0,116$ & 0,515 \\
\hline
\end{tabular}

By analyzing the criteria and alternatives for choosing the ergonomically most suitable design solution for the transportation of persons with physical disabilities in the Republic of Serbia, the solutions for retrofitting the existing vehicles into special purpose vehicles have been proposed, as shown in Figure 2. 


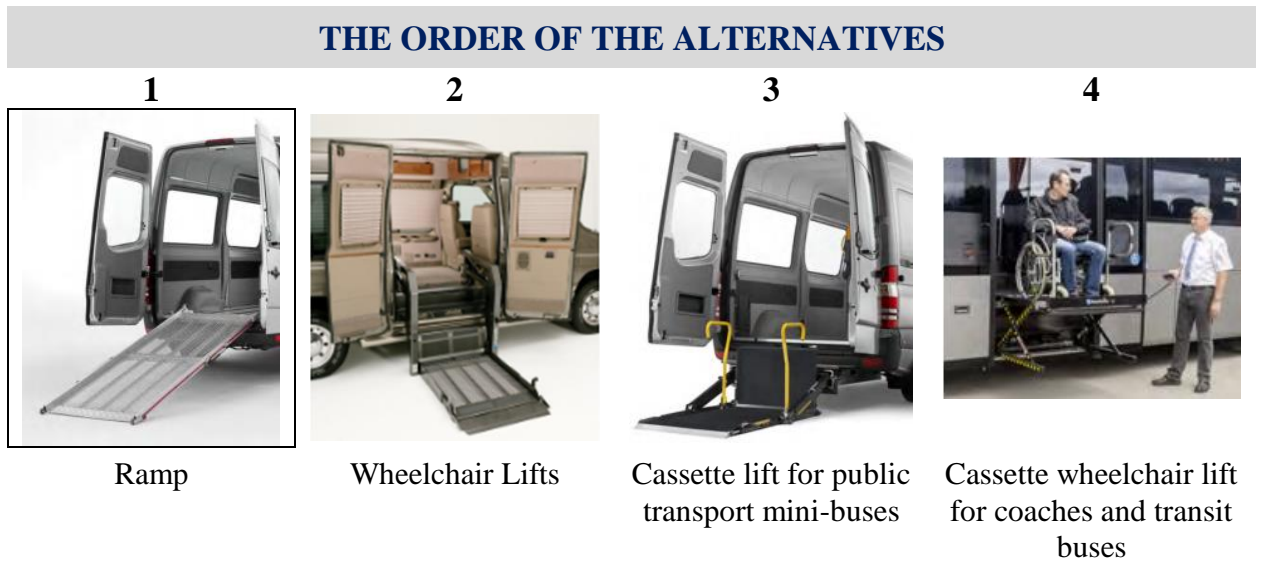

Fig. 2 Ranking the alternatives relating to the research problem

\section{CONCLUSION}

Persons with disabilities, including persons with movement disabilities, represent the "vulnerable" category of employees who need to be given particular attention throughout their life and professional development. First of all, it involves the support in their employment careers, the adaptation of the work process to their remaining capacities, acceptance by the collective, creation of opportunities for their improvement, progress and similar. We are now witnessing a large number of problems that make it difficult for persons with disabilities to find jobs and participate in the labour market. Some of the key problems are architectural barriers and architectural limitations on the one hand, and the problem of organized transportation on the other.

Since architectural barriers are issue that needs to be addressed systematically, and it also takes a long time to eliminate all infrastructure failures from the past, this paper deals with the issue of organized transportation for employees with physical disabilities using the AHP method. This method is a widespread tool and is increasingly used when solving complex problems and making important decisions. It refers to, first and foremost, the setting of the most realistically important criteria to be considered in order to select the most suitable alternative.

Having analyzed some of the contemporary solutions, as well as the criteria for each of these solutions, it can be concluded that the most suitable solution for retrofitting already existing vehicles into vehicles intended for special purposes and transportation of persons with movement disabilities in our country are the so-called ramps. The most important parameters which made the ramp the ergonomically and economically suitable solution are their cost and ease of installation, without additional vehicle adjustments. 


\section{REFERENCES}

1. Tatic, D., Prijic, T. (2015). Vodic kroz prava osoba sa invaliditetom u Republici Srbiji. NOOIS, Ministarstvo za rad, zaposljavanje, boracka i socijalna pitanja, Beograd.

2. National organization of persons with disabilities of Serbia (NOOIS) (Retrieved from http://noois.rs/).

3. Zakon o planiranju i izgradnji ("Službeni glasnik RS", br. 37/2019), član 5, stav 1

4. Dimitrijević, B. (2016). Prepreke u zapošljavanju osoba sa telesnim invaliditetom u Srbiji. Doktorska disertacija, Fakultet političkih nauka, Univerzitet u Beogradu.

5. Saaty, T.L. (1980). The analytic hierarchy process. New York: McGraw-Hill

6. Janackovic, G., Stojiljkovic, E., Grozdanovic, M. Selection of key indicators for the improvement of occupational safety system in electricity distribution companies. Safety Science, https://doi.org/10.1016/ j.ssci.2017.07.009.

7. Hot, I. F. (2014). Upravljanje izradom generalnih projekata u oblasti infrastrukture primenom višekriterijumske analize. Doktorska disertacija, Fakultet tehničkih nauka, Univerzitet u Novom Sadu.

8. Mimovic, P. (2006). AHP kao metod predviđanja ekonomskih pojava evaluacijom alternativnih budućih ishoda. Doktorska disertacija, Ekonomski fakultet, Univerzitet u Kragujevcu.

9. Metoda analitičkih hijerarhijskih procesa (Retrieved from https://bit.ly/2YavFB1).

10. Gorener, A., Toker, K., Ulucay, K. (2012). Application of Combined SWOT and AHP: A Case Study for a Manufacturing Firm. Procedia -Social and Behavioral Sciences, 58 (2012) 1525-1534.

11. Saaty, T.L., (1989). Group Decision Making and the AHP. Golden, B.L., Wasil, E.A. and Harker, P.T. (Eds.), The Analytic Hierarchy Process: Applications and Studies. Springer-Verlag, New York, 59-67.

12. Triantaphyllou, E., Shu, B., Sanchez, S.N., Ray, T., (1998). Multi -criteria decision making: an operations research approach. Encyclopedia of Electrical and Elctronics Engineering, John-Wiley \& Sons, New York.

13. Saaty, T.L. (2000). Fundamentals of Decision Making and Priority Theory with the Analytic Hierarchy Process. RWS Publications, Pittsburgh, USA.

14. Janjić, A., Savić, S., Janaćković, G. (2013). Multicriteria Methods for Distributed Generation Resources Optimization. Journal of Energy and Power Engineering, 7 (2013), 987-994.

15. Saaty, T.L. (1999). Creative Thinking, Problem Solving and Decision Making. RWS Publications, Pittsburgh, USA.

\section{PROCENA ERGONOMSKE PODOBNOSTI VOZILA NAMENJENIH ZAPOSLENIMA SA TELESNIM INVALIDITETOM - AHP PRISTUP}

Zaštita prava $i$ bezbednost osoba sa invaliditetom jedan je od najdelikatnijih elemenata društveno-razvojne, ekonomske i pre svega socijalne politike uopšte. Zbog toga se položaj osoba sa invaliditetom danas mora posmatrati pre svega kao pitanje ljudskih prava. Jedan od problema prilikom zapošljavanja osoba sa telesnim invaliditetom jeste infrastrukturne prirode (arhitektonske barijere), sa jedne strane, i organizovani prevoz, sa druge strane. Osnovni cilj ovog rada je sagledavanje problema prevoza zaposlenih sa telesnim invaliditetom, što predstavlja jedan od značajnih faktora prilikom zapošljavanja ovih lica u Republici Srbiji. Krajnji cilj ovog rada jeste da se primenom AHP metode utvrdi ergonomski najpodobnije i ekonomski najprihvatljivije tehničko rešenje prilikom prilagođavanja postojećih vozila u vozila namenjena za prevoz nepokretnih osoba.

Ključne reči: Analitički hijerarhijski proces (AHP), korektivna ergonomija, invaliditet, prevoz. zaposlenih sa telesnim invaliditetom, podizna platforma, kasetni lift za minibus, kasetni lift za autobus, rampa. 